\title{
PENGARUH MEDIA CERITA BERGAMBAR TERHADAP KEMAMPUAN LITERASI AWAL ANAK USIA 4-5 TAHUN
}

\author{
Thea Yesika Farodhy ${ }^{1}$, Novianti Retno Utami ${ }^{2}$ \\ Pendidikan Guru Pendidikan Anak Usia Dini \\ Universitas PGRI Yogyakarta \\ novianti@upy.ac.id
}

\begin{abstract}
Abstrak:
Media cerita bergambar adalah perpaduan antara media cerita dan media gambar yang berkaitan dengan cerita yang disajikan, sehingga perpaduan dari media cerita dan gambar dapat menjadi satu kesatuan yang saling mendukung. Tujuan dari penelitian ini yaitu untuk menguji pengaruh media cerita bergambar terhadap literasi awal anak usia 4-5 tahun. Hipotesis yang diajukan yaitu media cerita bergambar efektif dalam meningkatkan kemampuan literasi awal anak usia 4-5 tahun. Metode yang digunakan dalam penelitian ini yaitu metode penelitian quasi experiment, the one group pretest-posttest design. Subyek dalam penelitian ini adalah 19 anak usia 4-5 tahun di BA Aisyiyah Banyudono 1. Teknik pengumpulan data dalam penelitian ini menggunakan tes literasi awal anak menggunakan instrumen Get Ready To Read. Teknik analisis data dalam penelitian ini menggunakan Uji Wilcoxon untuk melihat tingkat signifikansi hasil literasi awal anak sebelum dan sesudah dilakukan perlakuan. Hasil penelitian menunjukkan asymp.sig. (2 tailed) 0,000. Nilai sig $0,000>0,05$ maka media cerita bergambar efektif dalam meningkatkan kemampuan literasi awal anak usia 4-5 tahun
\end{abstract}

Kata Kunci: kemampuan literasi awal, media, cerita bergambar

\section{THE EFFECT OF DRAWING STORY MEDIA ON THE EARLY LITERATION ABILITIES OF CHILDREN AT 4-5 YEARS OF AGE}

\begin{abstract}
:
Pictorial media stories are a combination of media stories and media images related to the stories presented, so that the combination of media stories and images can become a mutually supportive unit. The purpose of this study is to examine the effect of pictorial story media on early literacy of children aged 4-5 years. The hypothesis proposed is that pictorial media stories are effective in improving the early literacy skills of children aged 4-5 years. The method used in this research is a quasi-experimental research method, one group pretest-posttest design. The subjects in this study were 19 children aged 4-5 years at BA Aisyiyah Banyudono 1. The technique of studying the data in this study used an early children's literacy test using the Get Ready To Read instrument. The data analysis technique in this study used the Wilcoxon test to see the significance level of children's early literacy results before and after treatment. The results showed asymp.sig. (2 heads) 0,000. The sig value of 0.000>0.05 means that pictorial media stories are effective in increasing the early literacy skills of children aged 4-5 years
\end{abstract}

Keywords: early literacy skills, media, pictorial stories 


\section{PENDAHULUAN}

Anak usia dini biasa disebut dengan usia emas (golden age) usia emas terjadi pada usia lahir sampai dengan enam tahun (Apriyanti, 2017). Disebut sebagai usia emas dikarenakan semua aspek perkembangan dan pertumbuhan pada anak berkembang dengan pesat termasuk dengan kemampuan literasi awal anak. Kemampuan literasi awal anak merupakan pengetahuan, sikap serta keterampilan seorang anak yang berkaitan dengan membaca dan menulis sebelum anak menguasai kemampuan formal pada usia sekolah. Kemampuan literasi awal anak, akan mempengaruhi kemampuan literasi anak di masa yang akan datang. Artinya, kemampuan literasi siswa Sekolah Dasar dipengaruhi juga oleh stimulasi yang diterima anak saat sebelum masuk jenjang sekolah dasar (Kennedy, 2012;190). Oleh karena itu, sangatlah penting untuk membiasakan anak melakukan aktivitas literasi sejak usia dini, baik dilakukan di rumah sebagai aktivitas literasi dengan orang tua, maupun disekolah sebagai pembelajaran literasi yang dilakukan bersama dengan guru.

Joyce, Weil \& Chalboun dalam (Engelbertus Nggalu Bali, Fakhrudin, 2016) menerangkan bahwa anak belajar literasi awal secara alamiah. Dengan demikian periode literasi awal anak dimulai dari lahir sampai dengan usia enam tahun. Pada periode tersebut anak memperoleh pengetahuan mengenai membaca dan menulis melalui perilaku sederhana dengan cara mengamati dan berpartisipasi langsung melalui aktivitas yang berkaitan dengan literasi awal.

Menurut Snow (dalam Hoff, 2005), anak usia 2 sampai 5 tahun sudah dapat menunjukan kemampuan literasinya dengan cukup pesat. Pada usia $0-3$ tahun, seharusnya anak mampu mengenali buku melalui sampul, menuliskan huruf, mendengarkan cerita, berpura-pura membaca. Kemudian, anak pada usia $3-4$ tahun sudah dapat mengenali tulisan sederhana, mengenal bunyi bahasa yang berbeda, menghubungkan cerita di buku dengan kenyataan, tertarik untuk membaca buku. Pada usia 5 tahun anak seharusnya sudah mampu memprediksian alur cerita dalam buku, mampu menulis nama dan kata dengan dikte.

Kemampuan literasi awal di Indonesia masih rendah, hal tersebut dapat kita lihat pada hasil penelitian yang dilakukan oleh Organisasi Pengembang Kerjasama Ekonomi (OECD) yang menunjukkan budaya baca masyarakat Indonesia menduduki posisi terendah dari 52 negara di kawasan Asia Timur. Hal tersebut juga diperkuat oleh temuan IEA Study of Reading Literacy, yang menunjukkan kemampuan anak Sekolah Dasar di Indonesia masih sangat rendah, di mana dari 31 negara yang diteliti, Indonesia menduduki urutan ke 30. Penelitian Farida (2002) memperlihatkan bahwa kesulitan yang ditemukan pada anak di Indonesia adalah kemampuan dasar bahasa di usia dini (Hapsari, Ruhaena, \& Pratisti, 2017).

Hasil observasi dan pre test di BA Aisyiyah Banyudono 1 Kabupaten Magelang juga menunjukkan kemampuan literasi anak kelas B masih rendah, hal tersebut dapat dilihat pada kemampuan anak dalam membaca dan menulis. Hasil pre test menunjukkan skor rata-rata 5,68 dengan asumsi literasi awal anak masih rendah dan anak membutuhkan stimulasi yang tepat untuk meningkatkan literasi awal anak.

Mengingat karakteristik anak yang aktif bermain, bersifat egosentris, bersifat fisiognomis, dan memiliki kesatuan jasmani dan rohani yang hampir tidak terpisahkan, maka pembelajaran di taman kanak-kanak harus melibatkan banyak aktivitas bermain didalamnya. Pembelajaran untuk anak akan lebih efektif jika disesuaikan dengan minat anak yaitu dengan bermain. Prinsip belajar dengan bermain tidak boleh dihilang pada pembelajaran di PAUD, khususnya pada 
pembelajaran literasi (Basyiroh, 2017). Bermain merupakan cara untuk melatih anak memusatkan perhatiannya karena ketika anak sedang eksplorasi bermain, anak mencapai konsentrasi tingkat tinggi. Selain itu, bermain mampu menciptakan kegiatan belajar yang efektif karena menciptakan rasa senang dan tanpa tekanan. Menurut Vygotsky (1978), anak akan secara aktif menyusun pengetahuan dan memberi fokus pada bagaimana pentingnya interaksi sosial budaya terhadap perkembangan kognitif mereka. Dengan demikian, perkembangan kognitif anak dipengaruhi oleh pola interaksi dengan orang-orang terdekat anak, yaitu bagaimana orang tua dan guru memberikan stimulasi kemampuan literasi pada anak

Untuk meningkatkan literasi awal anak di BA Aisyiyah Banyudono 1 Kabupaten Magelang, peneliti menggunakan media cerita bergambar untuk menstimulus kemampuan literasi anak. Media cerita bergambar dibuat dengan memadukan antara media cerita dan media gambar yang berkaitan dengan cerita yang disajikan, sehingga perpaduan dari media cerita dan gambar dapat menjadi satu kesatuan yang saling mendukung. Pemilihan media cerita bergambar betujuan untuk memberikan ilustrasi kepada anak sehingga akan membantu anak dalam menggali imajinasi dan kemampuan literasi awal anak (Salamah, 2017).

\section{METODE}

Variabel yang diteliti pada penelitian ini yaitu: media cerita bergambar sebagai variabel bebas atau treatment, serta kemampuan literasi awal anak sebagai variabel terikat. Subyek dalam penelitian ini adalah Kelas A BA Banyudono 2 Dukun Kabupaten Magelang yang berjumlah 19 anak. Penelitian ini menggunakan metode quasi experiment. Metode dalam penelitian ini adalah penelitian eksperimen the one group pretest-posttest design. Desain ini memiliki perlakuan dan pengukuran dampak dengan melihat hasil pretest dan postest pada kelas eksperimen setelah diberikan perlakukan melalui media cerita bergambar. Penelitian ini hanya menggunakan satu kelompok tanpa ada kelompok pembanding. Populasi dalam penelitian ini yaitu BA Banyudono 1 Dukun Kabupaten Magelang dengan subyek penelitian TK A yang berjumlah 19 Siswa. Teknik pengumpulan data dalam penelitian ini menggunakan tes literasi awal anak menggunakan instrumen Get Ready To Read. Teknik analisis data dalam penelitian ini menggunakan Uji Wilcoxon untuk melihat tingkat signifikansi hasil literasi awal anak sebelum dan sesudah dilakukan perlakuan.

\section{HASIL DAN PEMBAHASAN}

Setiap anak memiliki kemampuan literasi awal yang berbeda-beda hal tersebut dipengaruhi oleh beberapa hal seperti latar pendidikan orang tua, usia anak, bimbingan belajar yang didapat, keluarga (tingkat kepedulian keluarga) dan gen (keturunan) (Saputri, Fauzi, \& Nurhaidah, 2017). Salah satu faktor yang paling berpengaruh adalah bimbingan belajar literasi yang diberikan ke anak. Bimbingan belajar bisa diberikan oleh orang tua maupun guru disekolahan. Hasil observasi dan tes literasi awal pada kelompok A di BA Aisyiyah Banyudono 1 menunjukkan kemampuan literasi yang rendah, terutama pada aspek pengenalan huruf . Hal tersebut terlihat dari 19 anak terdapat 11 orang anak yang masih belum bisa menuliskan huruf yang diminta oleh guru. Hasil wawancara terhadap guru kelompok A di BA Aisyiyah Banyudono 1 diketahui bahwa guru masih kurang dalam memberikan stimuluasi terkait dengan literasi awal anak, guru bisa dikatakan juga masih kurang dalam memanfaatkan media pembelajaran yang ada di sekitar sekolahan untuk pembelajaran literasi awal. Hal tersebut sejalan dengan hasil penelitian (Utami, 2019) yang menjelaskan 
bahwa saat ini guru masih banyak yang menggunakan metode konvensial yaitu guru mengajarkan anak untuk menghafalkan nama alfabet secara berulang dengan media papan tulis dan menirukan cara guru mengucapkannya. Berdasarkan informasi tersebut dapat ditarik kesimpulan bahwa rendahnya literasi awal di BA Aisyiyah Banyudono 1, salah satunya dipengaruhi oleh metode pembelajaran literasi yang masih kurang optimal.

Oleh karena itu guru harus mengenalkan kegiatan baca tulis pada anak dengan metode yang menyenangkan. Salah satu metode dalam pemberian stimulasi bagi anak salah satunya adalah dengan menggunakan media cerita bergambar. Cerita bergambar dipilih sebagai media pembelajaran di kelas karena mampu digunakan untuk menyampaikan pesan dengan efektif dan efisien melalui imajinasi anak (Indarni, 2012).

Hasil penelitian literasi awal di BA Aisyiyah Banyudono 1 pada kelompok A dengan jumlah subyek penelitian sebanyak 19, menunjukkan rata-rata pre test sebesar 5,68 dengan asumsi bawah literasi awal anak masih rendah dan membutuhkan stimulasi lebih dari guru. Setelah memperoleh perlakuan dengan menggunakan media pembelajaran cerita bergambar hasil post test menunjukkan nilai rata-rata 13,74 yang menunjukkan peningkatan. Untuk melihat nilai signifikansi hasil literasi awal anak sebelum dan sesudah dilakukan perlakuan, peneliti menggunakan uji Wilcoxon dengan bantuan program SPSS 20.0. Hasil perhitungan menunjukkan asymp.sig. (2 tailed) 0,000 . Nilai sig 0,000 >0,05 maka Ha diterima yang artinya perbedaan nilai post test menghasilkan nilai yang lebih tinggi dibanding dengan nilai pre test.

Hasil pretest dan posttest secara umum menunjukkan bahwa Ho ditolak maka Ha diterima. Hal tersebut anak sebagai responden dalam penelitian ini menunjukkan bahwa adanya peningkatan literasi awal anak yang signifikaan terhadap pemberian cerita bergambar. Kesimpulan yang dapat diambil adalah cerita bergambar dalam penelitian ini efektif digunakan untuk meningkatkan kemampuan literasi awal anak kelompok A di BA Aisyiyah Banyudono 1. Bagi anak usia dini cerita bergambar yang memenuhi kriteria bacaan berkualitas akan menjadi sumber yang baik bagi kemampuan literasi awal anak (Ambarwati, 2016). Anak usia dini belajar mencintai sastra melalui kesan yang menyenangkan dengan buku bergambar yang dibacakan oleh orang dewasa. Kesenangan yang diperoleh anak saat melihat buku cerita bergambar mampu meningkatkan literasi awal anak dengan baik (Jalongo, 2004).

\section{SIMPULAN}

Hasil penelitian menunjukkan bahwa penerapan media cerita bergambar sangat efektif dalam meningkatkan kemampuan literasi anak. Temuan selanjutnya adalah kesadaran guru dalam menerapkan strategi pembelajaran literasi yang tepat akan berpengaruh pada minat anak terhadap literasi dan kesuksesan pembelajaran literasi di kelas. Hal tersebut membuktikan bahwa dnegan memberikan rangsangan berupa media literasi yang tepat bagi anak dapat menumbuhkan minat anak untuk belajar baca tulis sehingga akan meningkatkan kemampuan literasi anak.

\section{DAFTAR PUSTAKA}

Ambarwati, A. (2016). Cerita Bergambar Untuk Anak Usia 0-3 Tahun Dalam Tinjauan Linguistik Fungsional Halliday, 2, 126-135.

Apriyanti, H. (2017). Jurnal Obsesi : Jurnal Pendidikan Anak Usia Dini Pemahaman Guru Pendidikan Anak Usia Dini terhadap Perencanaan, 1(2), 111-117. https://doi.org/10.31004/obsesi.v1 
i2.22

Basyiroh, I. (2017). Program Pengembangan Kemampuan Literasi Anak Usia Dini. Tunas Siliwangi, 3(2), 120-134.

Engelbertus Nggalu Bali, Fakhrudin, A. R. (2016). Pengembangan Model Pembelajaran Induktif Kata Bergambar Untuk Pengenalan Kemampuan Literasi Dini Aud. Journal of Primary Education, 5(2), 120-129.

Hapsari, W., Ruhaena, L., \& Pratisti, W. D. (2017). Peningkatan Kemampuan Literasi Awal Anak Prasekolah Melalui Program Stimulasi. Jurnal Psikologi, 44(3), 177. https://doi.org/10.22146/jpsi.1692 9

Indarni, N. (2012). Efektivitas Cerita Bergambar Terhadap Pemahaman Peran Gender Pada Anak Di Taman Kanak-Kanak. Indonesian Journal of Early Childhood Education Studies, 1(1), 5-9. https://doi.org/10.15294/ijeces.v1i 1.9196

Jalongo, M. R. (2004). Young Children and Picture Books. Washington DC: National As- sociation for The Education of Young Children.

Salamah, E. R. (2017). Media Cerita Bergambar untuk Meningkatkan Keterampilan Menulis Puisi Anak. PEDAGOGIA: Jurnal Pendidikan, 6(1), 43. https://doi.org/10.21070/pedagogi a.v6i1.616

Saputri, K., Fauzi, \& Nurhaidah. (2017). Faktor-Faktor yang Mempengaruhi Literasi Anak Kelas 1 SD Negeri 20 Banda Aceh. Jurnal Ilmiah Pendidikan Guru Sekolah Dasar, 2(1), 98104.

Utami, F. (2019). Pengaruh Penggunaan Aplikasi Bubybus Pada Gadget Terhadap Kemampuan Literasi Awal Pada Anak Kelompok A di PAUD IT Fathiyyah, 299-307. 